\title{
SOUTH KOREA - THE CRISIS-TORN TRANSITION TO A NEW MODE OF ACCUMULATION ${ }^{1 *}$
}

\author{
Holger HEIDE**
}

\section{Abstract}

The original Korean mode of accumulation was of great historic relevance for the process of modernisation which is the vital prerequisite for the valuation of capital. It was also highly efficient - particularly in relation to the development strategy in other countries. This, however, could only continue for the period of time during which the extensive utilisation of labour power was at least partially possible. Retrospective criticism is quite unfounded in this respect.

I the following I will make the attempt to show that it is the same powers who are responsible, not only for the original success, but also for the actual crisis. The development in South Korea over the whole period of the last half-century has been dependent on the one hand (domestically), on the role of world capital, which has tolerated and reinforced the accumulation regime. These two aspects are, of course, not to be seen separately, but rather as being interwined in a close global relationship.

The need to establish a new mode of accumulation results from the fact that the most powerful institutions of world capital have, for reasons of competition, dismantled the foundations of the Korean model and that, as a parallel development, for internal reasons the previously extremely effecient mode of accumulation has exhausted its scope for exploitation. The fact that the implementation of a new mode of accumulation manifests itself in crisis is due to the persistence of structures and to subjectively resistent action. That is true for those parts of the power-elite who fear to become thelossers of the expected "change", as well as for the resistent masses of workers, who only under threat of a "crisis" can be made willing to tighten their belts.

For me, the really crucial issue is the question for the possibility of an alternative - the development of solidarity.

1 I propose in the meantime to use the term "mode of accumulation" to illustrate that the thrust of my socio-economic approach goes beyond the approach of the regulation schoole and the subsequent Hirsch critique (Hirsch 1995) to include not only the relationship between political and $\theta 0$ onomic system, but also the relationship of structures with social action.

- I would like to thank the participants of The Social Economic Seminar of SEARI for their valuable comments and suggestions.

* Professor, Social Economic Action Research Institute, University of Bremen, Faculty of Economics. P.O.Box 330440, D-28334 Bremen, Germany; email: seari @ wiwi.uni-bremen.de; http $/ /$ www. wiwi.uni-bremen.de/seari 
Scientific theory would appear to be just as dependent on the cyclical fluctuation as are wages, prices and production. Perhaps it is no co-incidence that this applies especially to economic theories.

Thus, South Korea's economic boom and its successful integration in the world market -once it was perceived-has been put forward as evidence for the success of neo-liberal policies and, as such, prized as an example to be followed by other developing economies.

It was not until the second half of the eighties that a tendency to reorient this point of view began to emerge and, by and by, theories prizing Korea's economic miracle as an example for the efficiency of an optimally co-ordinated system of planning between industry, the banking system and state bureaucracy eventually gained supremacy.

Now that the crisis is upon us, it is the old arguments which are once again in demand: Clearly, it is postulated, government planning is fundamentally incapable of achieving efficiency. The lesson to be learned is that only the resolute implementation of liberalised markets can bring about the degree of efficiency needed to be competitive on world markets.

I wish to avoid subjecting myself to this type of cyclical fluctuation, even by way of taking an 'anti-cyclical' stance. It is my opinion that both schools are guilty of a generalisation of individually and separately correct observations, whilst not taking into account the historically changing conditions of the process of economic development. More crucially, though, in every case this preoccupation with the concept of efficiency obscures a true understanding of the fundamental prerequisites for capitalist accumulation.

In my opinion, it is neither true that there has never been any specifically South Korean model (e.g. Krugman), nor is it true that the functioning of the model is not in jeopardy following the current crisis (e.g. Sachs).

In the following I will make the attempt to show that it is the same powers who are responsible, not only for the success, but also for the crisis. The development in South Korea over the whole period of the last half-century has been dependent on the one hand (domestically), on the ability to mobilise its living human potential, and on the other hand (in an international context), on the role of world capital, which has tolerated and reinforced the accumulation regime. These two aspects are, of course, not to be seen separately, but rather as being intertwined in a close global relationship.

The need to establish a new mode of accumulation results from the fact that the most powerful institutions of world capital have, for reasons of competition, dismantled the foundations of the Korean model and that, as a parallel development, for internal reasons the previously extremely efficient mode of accumulation has exhausted its scope for exploitation. The fact that the implementation of a new mode of accumulation manifests itself in crisis will have to be dealt with separately. For me, the really crucial issue is the possibility of an alternative - the development of solidarity. 


\section{The problem}

\subsection{Krugman's thesis}

For to start with let me refer to some arguments of Paul Krugman of M.I.T. ${ }^{2}$, because at first sight they may seem rather convincing.

Krugman's argument consists of two main statements, one regarding the essence of the Korean (and East Asian in general) miracle, the other regarding the character and development of the subsequent crisis.

Krugman refuses all sorts of culturalistic attempts at an explanation of the "miracle". That's what distinguishes him from those whom he calls "the Asian leaders and their admirers". I agree with him in this important respect. But what is his consequence? Following an argument by Young and Lau, Krugman reduces the seeming miracle to what he calls "bred-and-butter economic forces", i.e. high savings rates, good education, and a movement of underemployed peasants into the modern sector (Krugman 1997). He then formulates: "Asian growth has so far been mainly a matter of perspiration rather than inspiration - of working harder, not smarter" (ibid.). Consequently he characterizes excessively rising wages and booming imports as an early sign of the diminishing returns that would - "sooner or later" - force a gradual slowdown in growth. When Krugman in August, 1997 wrote down these arguments, the final crash had not yet occurred. But what he already then stated was, that the financial problems having been obvious to policymakers for a long time, didn't lead to appropriate measures, but to mere temporizing by the government.

Regarding the "miracle" Krugman argues with what he calls "perspirationtheory". The facts he enumerates are clear. Obviously the total productivity numbers increase, when people move from less productive sectors to more productive ones. That's a statistical truth, not a theoretical one. From the standpoint of theory the finding is banal. The real problem that would have to be explained is how the process of structural change, which by the way is essentially identical with a vast internal migration, has been managed so efficiently in Korea ${ }^{3}$. Why didn't those millions of "redundant" people from the agrarian sector end up in the slums of Seoul definitly? (Many of them did so in the beginning, but most of them were later absorbed by the process of industrialization). From most other developing countries in Latin America, Africa and even Asia we do know lots of contrasting examples.

Reference to statistical truths doesn't explain anything at all.. The answering of the question requires an analysis of the South Korean mode of accumulation. This

3 In the following I will sometimes use the term "Korea" instead of "South Korea" or "The Republik of Korea". 
may imply the risk of becoming confronted with (for Krugman) unwanted results. Because in Korea, like in other Asian countries, it was definitely not the market which was responsable for an efficient allocation of resources.

\subsection{My argument in outline}

Krugman and other commentators create the impression that the problem is the crisis. Awareness of this fact helps to explain the ensuing debate on whether we are witnessing a conventional "currency crisis", or a "tinancial crisis", or some other phenomenon along these lines. And solely on this basis is it possible to justify Krugman's intensive treatment of the "moral hazard" argument. Whereas Krugman logically and systematically retraces the "mistakes" leading up to the crisis and subsequently declares the entire economic system built up in Korea since the 60 s to have been a mistake, my argument is as follows :

The original Korean mode of accumulation was of great historic relevance for the process of modernisation which is the vital prerequisite for the valuation of capital. It was also highly efficient - particularly in relation to the development strategy in other countries. This, however, could only continue for the period of time during which the extensive utilisation of labour power was at least partially possible. Retrospective criticism is quite unfounded in this respect.

My most important argument, though, is with regard to the "crisis" itself. Although it is undoubtedly true that the "crisis" can only partly be attributed to "capital strategy" in a subjective sense, and partly has manifested itseff "behind the backs of the actors", in my opinion it is still clearly discernible and also possible to substantiate theoretically that the crisis is the way of implementing a new mode of accumulation.

\section{The original mode of accumulation}

To enable a simplified overview, I have broken down the post-colonial period in Korea into six phases :

1. The phase of resistance and liberation

2. The phase of the lost revolution 1945 to 1953

3. The phase of stagnation and decay 1953 to 1961

4. The phase of development dictatorship 1961 to $1979^{4}$

5. The phase of repressed liberation 1981 to 1987

6. The phase of delayed democratisation 1987 to 1997.

4 I am aware that it may represent an oversimplification to include the whole Park Chung-Hee era in one single phase; it can be justified in this case because the paper is concerned foremost with the current crisis and it would be insignificant to take into account the breaks within the Park era. 
The latent crisis has always been present in capitalistic development, as can be seen. Therefore, according to the above breakdown, it is not possible to attribute a functioning mode of accumulation, or its crisis, to any of the phases. The first signs of crisis were already beginning to emerge in the latter hall of the seventies. Although they could be contained, they lived on latently. It was not until the phase after 1987 that the inevitability of the crisis of the mode of accumulation became fully apparent.

\subsection{A historical synopsis of the last five decades}

The following is an attempt to outline the main phases of economic and political development in South Korea since the liberation from Japanese colonialism in the late summer of 1945. Any division of history in phases is problematic, but as will become obvious, there are some peculiarities in recent Korean history that suggest differentiating certain phases.

As mentioned above I am proposing to distinguish between six main phases. Between the forced resignation of the first president Rhee Syngman and the successful coup of Park Chung-Hee, and once again between the assassination of Park and the coup of Chun Doo-Hwan, there were short additional periods of populist democracy.

The main power behind Korea's successful integration into the capitalist world market seems to be the strong state with the military and an effective secret service at its disposal. The Park regime, under which industrialization began, on the other hand cannot merely be interpreted as a regime of oppression. That would only managed to have squeezed begrudging performances out of the people. Obviously Park was successful in obtaining substantial popular support, at least temporarily. For instance, elections were held in which a majority voted for the dictator. On the other hand oppression does not automatically lead to successful capitalist development (Heide 1997 b, p. 7). In the world of today there are numerous examples of terrorist regimes in developing countries, if we talk about Cambodia or Myanmar in Asia, about Ruanda and others in Africa, about many regimes in Latin America, etc. The "successes" regarding developmental goals are almost negligible. A vivid example for this is also the situation after the Korean war in the second half of the 1950's.

So, let's have a short look now at the post-liberation history.

\section{a. Resistance and liberation}

Korean nationalism has a long anti-feudal / anti-foreign tradition. During the time of colonialism through Japan in the first half of this century, resistance became identical with anti-Japanism, and little by little a strong Korean nationalism de- 
veloped, with drastic demands for radical social changes of the old, late feudal social structures which were an impediment to any progress.

For the development of a progressive resistance movement, the bitter experiences of oppression, on the one hand, and on the other the circulation of revolutionary ideas among the youth, who especially through the war had been torn away from the old village community, played an important role.

The will for liberation that had developed and accumulated for decades, burst out with the impending defeat of Japan in the Pacific War in the summer of 1945. In many villages and cities liberation committees were organized that took over the real power and administration after the retreat of the Japanese army and police. A provisional National Assembly was prepared in Seoul.

The basic popular demands included the expropriation of the big landowners and the distribution of the land to the peasants. On this basis the National peasants association was founded. The workers, still a very small minority in society, founded a national association of trade unions, too.

\section{b. The lost revolution, $1945-53$}

With the invasion of the US army in Seoul on September 8, 1945, the elimination of this progressive movement began. The prevention of the National Assembly and the appointment of an American military government, the elimination of local self-administration and finally the ban of the trade union and peasants associations initiated a phase in which the resistance step by step developed into a guerrilla movement. Before the beginning of the Korean War, the anti-guerrilla warfare had already claimed 200000 dead.

In the Korean War that dragged on until 1953, changing wide parts of the country into a crater landscape through various captures and re-captures under the deployment of napalm blanket-bombs of the US ainforce, millions of people lost their lives and homes, and this finally sealed the division of the county near the border where the war had started. It was this experience that led to the elimination of the idea of an alternative to the capitalist system.

\section{c. Stagnation and decay, $1953-60$}

The preconditions for a capitalist development were extremely bad, because on the basis of resignation and hopelessness a societal dynamic cannot emerge. And, indeed, the country sank into poverty and stagnation for the rest of the decade. The South Korean regime under the aged dictator Rhee Syngman based on the very beginnings of the State-Chaebol-Complex, a corrupt nepotism of state administration 
and "bureaucracy capital". From that, a severe economic depression and election forgeny followed, leading to bloody revolts especially from students and finally to the resignation of Rhee and to a democralic interlude.

The unfulfilled basic needs of the masses came to the fore; but in view of South Korea's dependence on the USA and the hindering, corrupt interests of a ruling elite a realization of their needs was out of the question, especially because of the disorientation and the lack of any definite line of the weak democratic forces. There was no notion of an alternative that could inspire the masses. The resulting, essentially populist policy almost immediately led to the complete ruination of public finances, and the country sank into virtual chaos.

\section{d. Development dictatorship, 1961 - 79}

That was the basis the armed forces found under Park Chung-Hee when they established a "development dictatorship" with their coup in 1960. Park quickly recognized that the new industrialists, who were in a way "fed up" in the years before, could be important partners in accomplishing his development plans. By including them in the new dynamic development policy, the former "bureaucratic capital" became dependent on the economic interests of the government and at the same time was supported by the new ruling class (compare Lee 1993, p. 80). There is widespread agreement in the literature that the coup was in general seen to be a "release".

The pillars of the Park development policy were:

- the establishment of an efficient state bureaucracy and a tight central planning apparatus;

- the systematic preference for big combines (Chaebol) regarding the allocation of the big development plans.

- the dynamic extension of the education system from bottom up with the goal of (a) ideological and (b) professional qualities;

- the systematic planning (5 year plans) to establish an efficient economic structure from bottom up (basic infrastructure - light industry - heavy industry - high technology).

The planning system, that has efficiently functioned for three decades, is the center of the State-Chaebol-Complex. In an analysis of the OECD this is characterized as planning within a "quasi-internal organization" (Lee, 1995).

Essential for the outstanding efficiency of the Korean central planning was the fact that the government resisted the temptation to control the whole economic process in a bureaucratic way. The tight prescriptive planning was concentrated on a 
few strategic sectors and companies. Due to this, the left-out areas were not solely discriminated; at the same time they were left free to find their own supplier and sales connections. This prevented the discriminated sectors from becoming demotivated, a problem often observed in socialist countries. On the contrary, they were motivated to develop ever-increasing productivity and to contribute to the enforcement of low wages by the possibility of passing on the pressure of the market.

The forced pace of heavy industrialisation during the latter half of the seventies led to a widening of the gap between rich and poor. This gigantic investment programme, which was causing a growing deficit in the balance of payments, was accompanied by an attempt to use the market to pass "down" the costs onto the working population. Eventually, this overstrained the ability of the state to stabilise the social climate. The Park era was ended by the assassination of the dictator in 1979.

\section{e. The stopped liberation $81-87$}

The economic and ensuing moral crisis which the military dictatorship found itself in throughout the second half of the seventies was not overcome by the assassination of Park in 1979. The initially freed democratic powers were, as was to be expected, quite incapable of coping with the economic crisis and the pent up demand for a redistribution of wealth, so that the putsch led by General Chun Doo-Hwan in the Spring of 1981 was able to appear as a reinstatement of order, in particular in the eyes of the US government and the organisations of world capital. Top priority for this terrorist order was the strict policy of containment with regard to scoical demands so that industry could once again enjoy the scope to continue its export offensive. True, despite the terror it was only possible to maintain stability for a few years, but the groundwork laid in the first half of the eighties made the development after 1987 economically feasible.

\subsection{The concept for development policies}

With regard to content the Korean development strategy can be described as a successful attempt at systematically upgrading the economic structure, that in turn has successively been bolstered by the extension of an economic and, by and by, also social infrastructure.

The underlying concept was strategically dynamic. Fundamental to the concept was a purposeful selection of strategically important industries which either had to be built up from scratch, or were to be fostered with the purpose of increasing productivity. The comprehensive protectionism and detailed prescriptive planning were never intended to serve the purpose of conserving obsolete and subsequently uncompetitive production processes. Quite the contrary: On the one hand, privileges 
were closely tied to advances in productivity, and on the other hand, enterprises which failed to utilise the proffered protection and development grants to increase efficiency were summarily excluded from receiving assistance.

The logic behind this development strategy is awareness of the fact that the mostly lacking linkages in the event of a sustained development present such high risks for private capital that investment vital to development would not take place in the absence of strategic state control. Hence, the necessity to shield and foster the economy. The minimising of risks by way of state policy thus assumes the character of being prerequisite for production, or an infrastructure investment.

Should the realisation of investment and production decisions be left to private capital, however, the success of such a policy is tied to three conditions: First, the state must be strong enough to ensure the implementation of a convincing overall strategy, and secondly the state bureaucracy must be sufficiently competent as to determine correctly the crucial selection of suitable industries and policies; and the state must resist the temptation to take control of the entire economic process. These conditions were fulfilled in Korea, that is to say, they were developed. A particularly effective instrument proved to be the concentration of concise planning onto a few selected strategic sectors; the effect was not only discrimination against the remaining sectors, since on the other hand they were quite free to search for their own suppliers and selling markets. In this way it could be avoided that the discriminated sectors became demotivated, as so often happened in socialist economies. Thus the opportunity and motivation was provided to pass on pressure through the markets, to constantly move towards higher productivity and depress wage costs.

However, what may in retrospect appear to be a logical development strategy (e.g. see Chang 1993), has in reality been an extremely contradictory process thwart with a number of large and small social eruptions.

The transition from a policy of import substitution to one of enforced export, the transition from a policy of promoting light industry to one of supporting heavy industry and the transition from financing development with foreign loans to one of determined encouragement for direct investment, all these transitions constituted diversions of the strategy; they constituted a reaction to failures of the previous policies, partly triggered by changes in conditions within the world economy, and partly due to domestic social change within.

The fact that the system and the state was able to survive these upheavals and managed to maintain stability was because the ruling classes were able to react flexibly: regimes were toppled (in the case of the initiator of the development dictatorship of Park Chung-Hee there was even resort to murder), and there were frequent concessions to democratic intermezzos where this was perceived as being inevitable. Then, in the absence of any real alternative, these democratic intervals together with 
their incumbent populist policies were doomed to failure when faced with obstruction from the forces possessing the real power. In each case, therefore, the way was paved for the next putsch.

In this way it was possible to deal successfully with all the severe political crises as mere crises of specific policies and their perpetrators, and thus a crisis of the state was avoided.

\subsection{The secret of the miracle: The readiness of society to overexploit itself}

The expansive development of the Korean economy and society first began, as we have seen, with the Park regime, i.e. after 1961. Any ideas representing an alternative to capitalistic development which may have existed at the time of the liberation from Japanese rule must obviously, together their protagonists, have perished in the following periods of counter-guerrilla warfare and the Korea War.

My thesis is that the phase beginning with the US army landings in Inchon witnessed a battle against all progressive ideas and persons who did not conform to the American ideal, culminating in the terror and physical destruction which reached its zenith in the Korea War. These events gave birth to a trauma, leading to a kind of collective "identification with the aggressor". This traumatic identification constitutes the erasure of consciousness with regard to history - the incapacity to accept responsibility for one's own action and the punishment for suppressed elements of Self in the form of anti-communistic hysteria (the "red complex").

Throughout this whole period, often referred to as the Korean miracle and which I have labelled as the original Korean mode of accumulation, the Korean society was living off their resources.

Since capitalist accumulation can never be a sell-sufficient, self-contained system (a perpetuum mobile), but rather is dependent on the intake of living energy, it is destructive by way of definition. This is also true for inward society, i.e. for the individuals in society who have internalised the imperatives of the system, it is true for the destruction of nature and ultimately - increasingly with the expansive power of the individual's own system for external social and cultural interrelationships.

We will remain at first within the national context. The inheritance of the period between 45 and 53 was a fear of the fear of weakness, resulting in the necessity for its suppression. This entailed, though, the suppression of feelings, thoughts and the action which was the cause of defeat. Collectively, this took the form of contempt and aggression against the (weaker) minority of those who, rightly or wrongly, could be

5 A detailed examination of the concept "identification with the aggressor" can be found in Heide 1998; for the original psycho-analytical verification of the concept see Hirsch 1996; Ferenci 1933;

A. Freud 1980. 
associated with those feelings, thoughts and action. This auto-aggressiveness, which manifested itself in self-sacrifice for the system, was subsequently accompanied with disdain for weaker members of society. The widespread - partly open, partly covert aggression against children, old people, the handicapped, migrant workers, etc.

In individual psychology, this is known as the separation from Self, conform with a loss of spirituality. In a social context this equates with the separation (or elienation) from one's own history, or as Marx put it: "Individuals (have) alienated their own societal relation as an object from themselves" (Marx 1939, p. 78). Once the belief in an alternative has been thoroughly destroyed, individuals develop an interest in participating in capitalistic society to whatever extent that entering into competition appears as prerequisite to their survival. In other words, they eventually develop a "private interest" that "can only be achieved with the means provided and within the conditions laid down by society; and thus is linked to the reproduction of these conditions and means" (Marx 1939, p. 74).

After 1953, anti-communism was the sole focus for identification. This gave rise to disappointment in the aggressor's weakness, which was now becoming apparent, and made it more difficult to come to terms with defeat (cf. Henderson 1968, pp 175). This was the more profound reason for the lethargy, resignation, and passiveness which was unable to offer a basis for any kind of development.

Park, with his vision, came onto the scene at the right time (ct. Lee, E.J. 1995) and his putsch was perceived as "deliverance", as release from social paralysis.

This point was the beginning of building up a society on the basis of aggressiveness. Its most significant forms were militarism and unrestrained competition. The term "number one" not only became the leading motif for the economic development strategy, but also for the unrelenting struggle of all against all. Whereas the official propaganda theme was: "We must become number one in the economic struggle against the rest of the world", the hidden message was: "All individuals are on their own in the struggle of competition!" The supposedly East-Asian characteristic importance of the family, so often acclaimed in the West, has its origin in the fact that the family had not yet been exhausted as a resource in the capitalistic process of development, not running up against the barriers of exploitation until the past two decades. And family ties and protection, on the other hand, mean an enormous burdening of responsibility on the individual to survive the competition for which the family makes him fit.

\subsection{Symptoms of the consequences}

Since introjective identification constitutes a separation, or disunion from Self, the effect on individuals is that they lose the capability to recognise the limits of their natural capacity and to realise at which point increased effort leads to the ruination of 
their physical and psychic vitality. Here we are describing a problem of addiction (cf. Heide 1998). Also an indication for over-exploitation is the destruction of social relationships in which the individual is embedded, primarily the family in its broadest sense. By way of competition, as well as formal and informal structures, this addiction becomes generalised to the point that it becomes a social phenomenon, so that nowadays we can speak of an addictive society.

Part of the symptoms, which I interpret here as the symptoms of an addictive society, are what the proponents of the Korean development would acclaim as "virtues", especially the attitude to work, whereby the dependent workers exercise a sort of "self-sacrifice" in the production process for "their" company; other examples are "Hyundaiism" (Kang 1995), this time on the side of executives, or "management by stress", the attitude towards vulnerable social groups, such as old people, the handicapped, migrant workers, etc. There is also the behaviour of parents who, in an attempt to give their children a chance in life, literally nurse or work them to death (or at least suffer from poverty themselves), with the result that the children are exposed to virtual psychic terror (by the way, the children are later often objectively and subjectively incapable of caring for their parents in their old age due to their own addiction to work, caring for their own children on the one hand, and long working hours, impossibly small flats in overcrowded towns, on the other).

In public debate as well as in private conversation, there is a widespread sense of victimisation in Korea. One example for this is the repeatedly uttered protestation that in all its long history, Korea has never waged war against another country, but on the contrary, on innumerable occasions it is Korea which has been the victim of attack from outside. This argument is often employed to justify Korean nationalism as being quite harmless, as opposed to Japanese or German nationalism. A further example is Korea's role in the world economy, which on the one hand is accepted in an abstract way with the undisguised pride of having made this achievement without any outside assistance, but on the other hand tends to ignore the role of the SouthKorean Chaebol as exploiters of migrant workers. Despite this, the feeling is still prevalent that Korea is the victim of foreign capital (especially Japanese and American capital).

Since a sense of victimisation is an expression of non-acceptance of responsibility for one's own action, there is a danger that the sense of victimisation can be turned into justification for offensive behaviour, e.g. the attitude towards migrant workers, who are often defamed as spongers, attracted to Korea by the material wealth that the Koreans alone have created and thus should have the sole right to benefit from. It is my opinion that this habitual attitude is also attributable to identification.

Symptoms of addictive behaviour are also revealed in the social struggles. In my opinion, therefore, the obvious contradiction between the often very radical and 
militant form and the usually system-conform content of labour disputes are expression of the system imperative, which even in itself implies an internalisation of the inconsistency of the system.

\subsection{Preliminary conclusions}

Despite the repression, war and deportation under Japanese colonialism, after the liberation, there were still rich, unutilised prevailing capitalist conditions in place, the village community, extended family, etc. That this capacity remained unutilised implies that they were resistant to processes of capital realisation.

South Korea's history, especially the first eight years after liberation, is the history of shaping suitable subjects for capital realisation by means of massive terror. This resulted in an ideological and moral vacuum which led to a further seven years of stagnation and decomposition of society.

It was not until the putsch of 1961 that Park Chung-Hee created the possibility for an introjective identification with a programme of development dictatorship. This instilled in the Korean people the crucial basis for an aggressive capitalist development.

The mode of accumulation which was developed on this basis was characterised at the political level by a "strong state", capable of implementing the efficient and prescriptive strategic planning of investment and production and, at another level, the corresponding control by government, the banks and the Chaebol, hand in hand with an excessive expansion of the educational system to prepare a skilled workforce needed for the strategy.

Parallel to the implementation of these measures at the political level, in the actual production process a management system was developed, which entailed introjective identification in the form of identification with the firm and the bosses. This was bolstered -once again parallel to the social levet in the Chaebol by a combination of barrack-type discipline and paternalism, to which belonged -once more anchored in legislation at the political level- the so-called life-long employment for the parmanent workforce.

The outcomes were a systematic upgrading of the economic structure and sustained growth rates which surpassed the performance of virtually all other economies.

Of crucial significance is the simultaneity of the extensive and intensive utilisation of labour power accompanied by the consistent and extensive utilisation of environmental nature. Since the strategic planning needed to compensate for imbalances and selective protection from world market influences can only be ensured by a strong state, this simultaneity could never be achieved via free markets. 
The conclusions arrived at by some of the proponents of neo-liberal theory based on analysis of details concerning the current crisis, viz. that the entire Korean development model is ineffectual, is not simply over hasty, it is false. The model "Korea" has functioned; it has enabled the integration of a society within the capitalist world economy which was previously not receptive to capitalistic development, It enabled this not merely by means of absolute repression, but in an "intelligent" way. Capital seized the initiative, taking full advantage of the opportunity presented by identification and creating a cleverly-contrived adaptation of the "infant industry concept" for the formation phase.

\section{The crisis as implementation of a new mode of accumulation}

\subsection{The delayed democratisation 1987 to 1997}

The turn in 1987 was not the result of economic collapse or high unemployment. It was triggered by concessions to what in the meantime had become a powerful and active democratic movement, revealing at last the crisis of the old mode of accumulation. Despite fears of a new military putsch it nurtured the illusion that on the basis of the raised stage of development of the forces of production there could be a smooth transition to a modern welfare state along European lines.

In the eyes of the majority of people, it was simply a matter of extending the democratic state and securing a just share of GDP.

These hopes were to suffer constant setbacks. Although the political climate eased somewhat, the "National Security Law" was still in force and torture of political opponents was still on the agenda, especially on the part of the secret service organisation Angibu (the Korean CIA), the democratic unions were still illegal and the prisons were overflowing with activists who had tried to build up the unions or organise strikes.

This disillusionment could initially be compensated for and put out of people's minds in the wake of the significantly improved share of prosperity accruing to a large part of the population. This once again nurtured their hopes.

\subsection{The high price for loyalty}

In 1987, the strategy, introduced already in the latter half of the seventies by the automotive and heavy industrial sectors and reversed following the putsch of 1981, of paying higher wages to skilled workers became the rule. Alongside the existence of brutal repression exercised by employers as well as the state, and the paternal pseudo-family structures in enterprises, it was specifically the Chaebol who systematically changed their tactics to "buying" workers' loyalty through wage concessions. 
The conditions for this are twofold: On the one hand, structural conditions in large enterprises favoured union organisation industrial action, whilst on the other hand the profit margins of the Chaebol were substantially higher than those of small and medium-sized firms.

The effect of this strategy is illustrated, for instance, by the diverging wage differentials in relationship to the size of the enterprise.

The thesis that loyalty could be bought with the help of this strategy is supported by examples taken between the years 1987 - 1997. I would like to mention two examples here, one from the hot summer of " 87 " and one from the "1997" winter of industrial action.

The first example: The demands made by the workforce in the large enterprises of the Chaebol, e.g. Hyundai Heavy Industries in Ulsan, included in the following order "freedom to establish unions", "elimination of barrack-style discipline in factories", and last of all wage increases.

After weeks of extremely violent industrial action, the situation finally calmed down in September 1987. The reason behind this was the offer by the employers to nominally increase wages by up to $28 \%$. Barrack-style discipline remained unchanged and the unions were not legalised. The weeks following commencement of work were characterised by a significant increase in productivity.

The second example: After the nation-wide strike at the beginning of 1997, which followed the coup-like passing of stricter labour legislation as well as the $\mathrm{Na}$ tional Security Law in December 1997, numerous "workforces" volutarily introduced extra shitts, work on Saturdays and Sundays, all under the guise of not wanting to endanger their jobs by harming their "own" employer.

Apart from the representative examples mentioned here, the continued existence of the company union system substantiates my argument.

Since time immemorial, forces in the labour movement have fought to overcome the narrow-minded attitude of seeing things solely through the perspective of the company. Nevertheless, the mere fact that the solidarity principle has played a subordinate role to individual interests for such a long time is, by itself, an indication of the successful strategy employed by enterprises of granting wage concessions to ensure workers' loyalty.

What has now triggered the crisis is the fact that world market standards have driven the price of compensation for overexploiting the living labour power of society to too high a level. It is this aspect which lies behind the neo-liberal demand for the tightening of belts: The workers are to further permit being exploited, and they should be more modest in their claims for compensation. 


\subsection{Protraction of the adjustment process}

The benefits accruing to the active participants from the old system of planning and protection were so great that they found it impossible to give it up. It thus took tough negotiations within GATT (Uruguay Talks) accompanied by subsequent pressure from international capital and its organisations before the state-Chaebol complex could be moved to initiate its gradual self-dissolution.

The state-Chaebol complex was eventually drawn by this pressure into a virtual whirlpool of self-dissolution. Governmental and Chaebol leaders passed each other the buck for adjustment measures: The government tried per decree to enforce guidelines restricting wage increases and to influence the Chaebol to concentrate on limited areas of production. Whereas the Chaebol had for years been demanding a lifting of the ban on mass redundancies.

The protraction of adjustment, although resulting in billions of extra profits, on the other hand favoured conditions for corruption and "unproductive" investment and in particular it almost inevitably paved the way for the sudden adjustment culminating in the crisis.

The crucial factor which perhaps best illustrates the aspect of protracted adjustment is the administrative support for bolstering the exchange rate of the Won against the US\$. An earlier deregulation of the exchange rate, i.e. a transition to floating, would arguably have resulted in a slight trend to depreciation. This would have given a boost to Korean exports and alleviated the pressure (and reduced the chance) funnelling direct investment abroad.

The hypothetical case of slow adjustment, symbolised by the broken line, is not possible due to adherence to the hitherto proven mode of accumulation.

Large increases in productivity did not have to be completely transformed into real wage increases; nevertheless wages have increased rapidly - more than $400 \%$ in ten years. However, due to the strong Won, part of the available export revenue was used to increase the reserves of foreign currency instead of financing the wage increases. The currency reserves were then able to be used to acquire equity abroad.

This high external purchasing power of the Won, which had a retarding effect on the incomes of Korean workers, was however accepted due to the simple fact that inexpensive import of foreign consumer goods and trips abroad strengthened the self-esteem of many Koreans and the self-image of being "modern" and "open minded".

On the other hand, more and more relatively labour-intensive jobs were transferred abroad to countries where wages and other costs were lower. The situation can summed up as follows: The modernisation and rationalisation of Korean in- 
dustrial structure was accompanied by an increasing necessity to have goods consumed in Korea produced by foreigners, either abroad or in Korea itself by employing migrant workers from abroad.

\section{Figure 1: South Korea - GNP per Capita}

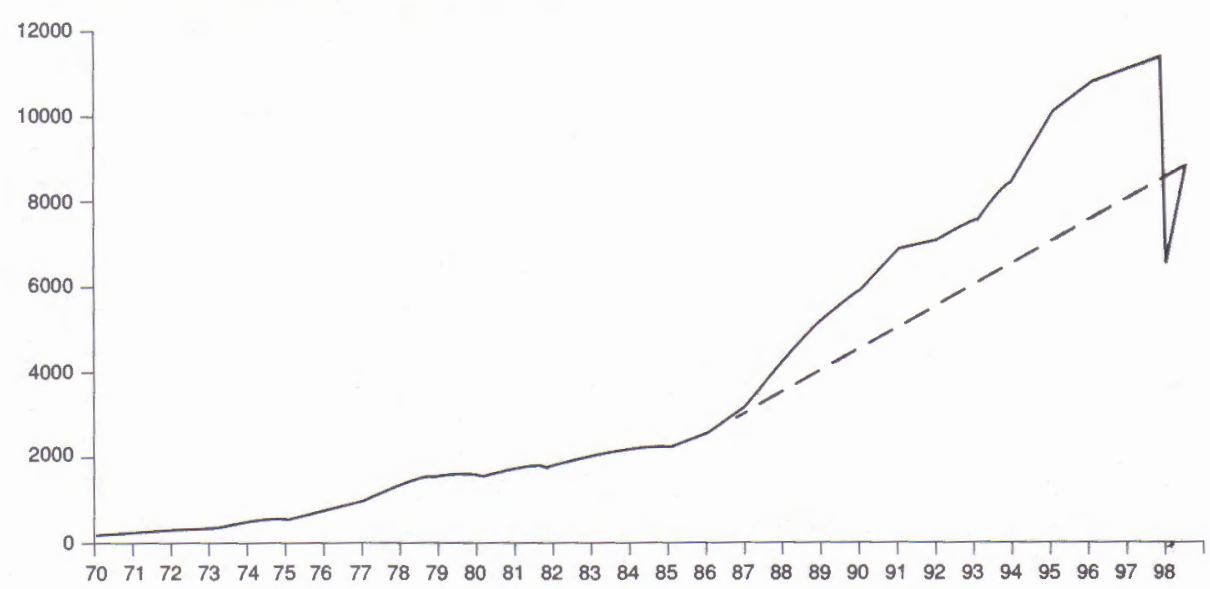

Source: Calculated from the Bank of Korea and for 1997 OECD (1998)

The rate is annual averege and for the value of 1997 calculated as the arithmetic mean of growth rate. The value of 1998 is estimated

\section{Figure 2: South Korea - Exchange Rates}

\section{US Dollar/100 Won}

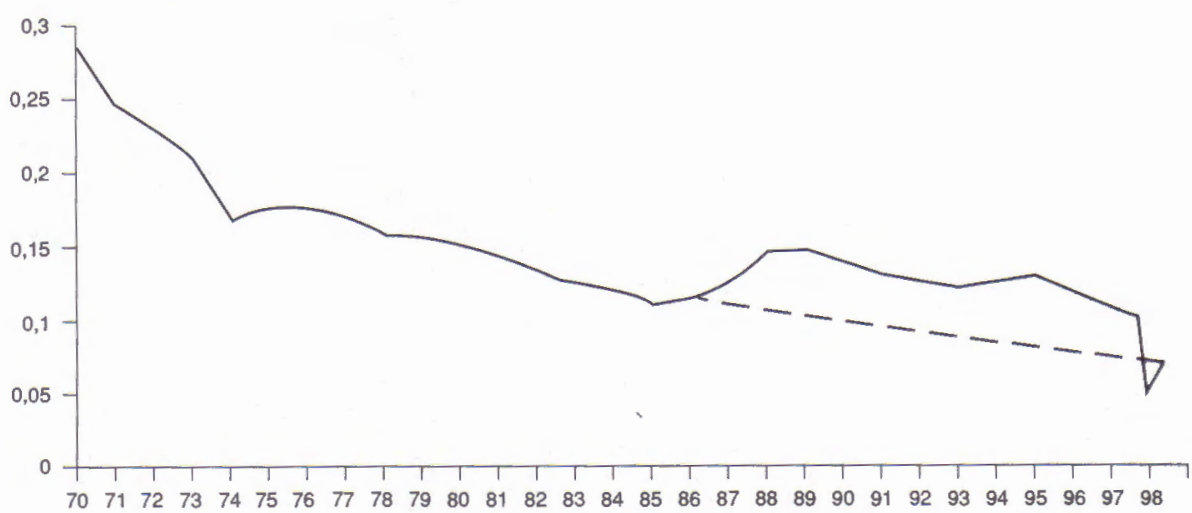

Source: Calculated from the Bank of Korea and for 1997 OECD (1998)

The rate is annual averege and for the value of 1997 calculated as the arithmetic mean of growth rate. The value of 1998 is estimated 
It seems that this system was able to function perfectly for years. Of course, it should not be overlooked that the problem was a result of the overvalued US\$ in particular, and thus other currencies -especially European- played a relatively insignificant role during the period when the dollar was weak. The situation had to deteriorate when, as has been the case in recent years, the US\$ began to appreciate. The problem remained latent, though, and only came to a head in the last four months of 1997 when share prices plummeted and the Won ended up by being devalued by $50 \%$. Why did the problems not occur earlier and what suddenly happened?

I have already characterised the function of a "strong state", and it is against this background that the situation can be clearly understood. As long as the confidence in the strength of the "tiger" remained unbroken capital could flow into Korea. The "strong state" was the guarantee for stability: Loans were not provided by the free market, but rather were largely allocated by the authorities, and industrialisation projects were certainly undertaken with government support. As a consequence, it was unimportant whether, for instance, short-term loans were used to finance longterm projects. The authorities provided assistance before an enterprise, or even a bank, slid into serious liquidity difficulties. This occurred frequently in the past.

The problem for the functionability of this system first arises when the state no longer has the power to intervene. And this is precisely what happened. In drawn-out negotiations, actually over a period of more than ten years, international capital had forced the Korean government (other governments as well) to introduce liberalisation and deregulation measures, in other words to open up their markets for goods and capital and to steadily cut back the level of state intervention ${ }^{6}$.

It is, of course, precisely this which has led to nationalistic reactions in Korea. Many Koreans feel that they are the victims of "foreign countries". Of course, there has been "pressure" on the government; but a closer look reveals that American capital is no more hostile than Korean capital. As we have just seen, Korean capital used the overvalued Won strategically to maximise its own profits, of course against American and European capital. The automobile Chaebols thus demanded tree access to foreign markets, but at the same time protected their own markets as much as possible through high import duties, specific import regulations, etc.

6 Regarding the OECD there was pressure untit the last minute before Korea's acceptance as a new member in this club of rich nations. "The archaic financial system is the chief obstacle to Korea's bid to become the first Asian Tiger to gain membership into the OECD" and "Concessions by the government to the opposition from the financial establishment ... are likely to diminish Korea's chances this year with the OECD. The organisation will probably see more progress on financial deregulation before giving the nod. Seoul needs to stop interfering in the capital market, if the OECD is to take Korea's bid seriously ..." (Lee, C.K., 1996). 
The result of this was economic war which could only end in liberalisation and deregulation. Neither the Korean authorities nor the Chaebols were sufficiently prepared for this predictable situation. Despite the results of the Uruguay Round, there was no change of policy: The Won was kept stable -i.e. overvalued- and financing terms were not adjusted to fall in line with the rules of the free market, for example the practice of providing short-term loans for long-term projects was continued, simply because they were cheaper.

The question is, however: Why did foreign lenders accept this situation? The answer is, they did not "accept the situation" as such, but rather went along with it because of potentially high profits. Nothing is as successful as success. As a result, as long as there are no doubts about the continuation of a situation, then it will continue.

Following the weaknesses in some other south-east Asian countries (Thailand, Indonesia), where Korean capital had made numerous acquisitions with the strong Won, the first cracks appeared in Korea. And, as the government no longer possessed anything like the same power as previously, it could only stand by and watch helplessly as the whole economy started to collapse. The was no possibility to counteract the crisis of confidence, as the government simply did not have the means to intervene.

Over time, the need for adjustment was becoming increasingly more evident and it was only the threats and intervention of the government which constantly put it off'. One of the most spectacular attempts to stage a crisis-coping strategy, whilst not triggering the crisis "too early" by so doing, was the furtive action surrounding attempts to amend the Labour and National Security Laws in December 1996.

That was an attempt to realise in essence the basic demands which have now been forced through by the IMF. Amended labour legislation then would have enabled mass redundancies a year earlier than those eventually made possible in February 1998.

\subsection{Preliminary conclusions}

After the phase of the articulation of different modes of production had ended with the extensive destruction of peasant farming, the first symptoms of crisis began to appear with the ever more frequent and bitter struggle for wealth distribution on the basis of the increasingly shorter supply of labour in the latter eighties. At first, this was countered by the ruling elite in the accustomed manner with a new military

7 In the meantime, an investigation committee has presented an intermediate report on the monetary policy of the government and central bank. The report shows that the government had strictly instructed the central bank to maintain the Won exchange rate in order not to endanger the chances of success of the ruling party's candidate in the presidential elections. 
putsch and subsequent repression. The breakthrough of the democratic and workers movements of 1987 hallowed a phase of establishing unions and successful redistribution struggles. The background to this was the advanced exhaustion of the forces which were still available at the beginning of the modernisation process.

At the same time the struggle for a regional redistribution of the valuation opportunities within world capital was concentrated and intensified. This struggle took place, with the exception of some less-civilised theatres, in the tough rounds of negotiations in GATT and the OECD. Especially during the Uruguay Talks and entry negotiations with the $O E C D^{8}$, elements essential to the functioning of the original mode of accumulation were dismantled.

Due to the more direct influence of the conditions of the world market, the diminuation of gratis productive forces manifested itself as increasing costs of reproduction for labour power. The transition to new, more intensive forms of exploitation (rationalisation) became inevitable. Whilst in the West it still remained to be seen how the apparently super-efficient East-Asian management techniques could be utilised, in Korea the technological prerequisites for drastic rationalisation were being developed.

A rapid implementation was obstructed by the objective persistence of prevailing structures and later on even by the subjective resistance of workers, who demanded a higher compensation for their sacrifice.

It was this protraction of rationalisation which eventually triggered the "crisis" and it is the "crisis" which now has made rationalisation unavoidable and thus possible.

\section{Crisis Management Strategies}

\subsection{International crisis management}

The overt crisis manifested itself in the sudden insolvency of the Korean economy with regard to its foreign debt. In such a situation there are basically two different strategies for dealing with the crisis: either to roll over the short-term loans, thereby extending the "fundamentally necessary period of adjustment", or "the drastic cure" with concisely formulated demands on the part of the creditors for an effective programme of adjustment in the short term.

Fearing negative repercussions for other parts of the world, especially the international competitiveness of weaker economies, one group of scientists proposed the

8 "Seoul needs to stop interferring in the capital markel, if the OECD is going to take Korea's bid serious", as Business Week already reported in August 1996 (Business Week, August 19, 1996, p. 22). 
first alternative. It is the hard-line IMF policy which was adopted. The focus of the catalogue of high-priority measures put forward by the IMF is designed to resolutely continue the strategy of liberalisation and deregulation of the capital market, which was partly to blame for the crisis in the first place, together with steps to abolish legislation restricting mass redundancies, to open up the possibility for foreign capital to purchase enterprises in Korea and to set an extremely high interest rate.

In reality social disparities are already increasing considerably. Due to the high interest level income from capital are growing and with these the sales of luxury goods, whereas poverty and indebtedness are increasing, too.

A certain part of the seemingly prompt results of the IMF measures are pure appearance ${ }^{9}$. The surprising balance of trade surplus is simply due to protracted imports of essential inputs for the domestic production process. Production of certain pharmaceutical products had already been stopped for the lack of raw materials. For other production processes the reserves are only sufficient for a quarter of a year.

\subsection{Domestic crisis management}

Kim Dae-Jungs governmental programme is an attempt to implement a sort of social democratic policies, however, the basis for this is missing. To date, social democratic policies have only been possible in highly industrialised countries which, due to their position in the world, have been able to impose a redistribution of globally produced goods in their favour and use this surplus to provide material incentives in order to pacity their working classes (but also other classes and groups) and, consequently, tie them to the system. Social democratic policies are not possible in the absence of a global redistribution.

The new government is faced with the following dilemma: To compensate for the bad loans, the Korean economy needs an injection of foreign capital which means that some of the productive wealth invested in Korea now has to be sold. The foreign exchange obtained from such sales are to prevent bankruptcy.

However, foreign investors demand a virtual guarantee for profits which, in turn, presupposes first and foremost a stable society. This is, on the other hand, almost impossible to guarantee when millions of workers and employees have to be made redundant in order to create the necessary downward pressure on wages and working conditions which is fundamental to South Korea's' competitiveness on the world market.

9 In march 1998 the forecast of the balance of payments surplus for the whole year 1998 was adjusted from originally USS 5 bn to USS 20 bn. Private research institutes are already expecting US\$ 50 bn (Korea Times, 03.18.98). 
It might be supposed that a social democratic strategy is precisely the way out of this dilemma. Namely, to establish an effective and comprehensive unemployment benefit system ${ }^{10}$ in order to ensure that redundant workers receive support to cover their cost of living. However, the problem is that this simply cannot be financed: Where should the additional finance come from, precisely at a point in time when the government is trying to save money everywhere? If only a relatively small percentage of unemployed people were involved, then a pure quantitative solution might be found to the problem. However, the originally estimated $5-7 \%$ unemployment rate has meanwhile been revised to at least $10 \%$. Since unemployment insurance contributions have not been allowed to accumulate over a longer period of time, funding would have to come from some other source. From taxes, perhaps? Who should pay them? There seems to be no solution to the problem.

From the point of view of the functioning of the system this unanswered question concerns the problem of social stability. A decisive characteristic of social democratic policy is the attempt to solve the class conflict. In Germany we can still remember the "concerted action" introduced by the social democratic finance minister Schiller. It is precisely this that the government is trying to implement in Korea at the moment: "Tripartite negotiations" between the government, employers and unions: "President Kim wants to hammer out a grand social pact whereby the three parties government, labor and management - agree to share the burden for revitalising the economy and repay the emergency loans from the IMF as soon as possible", formulated by one newspaper (Korea Herald, 3.2.98). And it actually seems to have been successful. The first time in the history of South Korea. However, there are limitations to social democratic policy in a not so wealthy and only recently industrialised societies. Union leaders may be willing to compromise, but they are not in a position to force their grass roots to accept the negotiated result without encountering resistance. As has been often the case in recent years, the negotiated compromise caused a rebellion amongst the grass-root members. The union leadership responsible was chased away and a strike called, and this time a general strike.

Two days later, however, the call for a general strike was withdrawn by the crisis committee. Does this mean that the left-wing members of the union "became reasonable" as was noted with relief by both the government and media?"

There are two facts behind the provisional leadership's decision:

1. a large majority of the workers and employees who should have gone on strike were, on the one hand, extremely angry, but nevertheless afraid that a

10 Initially a fund amounting to US\$ 3 bn will be made available.

11 Cf. "Seoul prosecutors warn of punishment on strike", report from CNN World News 12.02.98. 
strike would worsen the national catastrophe even further. It is difficult to say which is the greater, the anger or the fear.

2. the governments unequivocally indicated that all means at its disposal would be employed to counter a general strike.

The first point reflects that, once again, a combination of "truce" and nationalistic propaganda pays: Social antagonism is transformed into national antagonism. The success of the first aspect is a prerequisite for the functioning of the second point. As the majority of people, also workers, by and large accept the basic rules of the capitalistic system, they are easily convinced, or even convince themselves that if there is to be a Great Social Compromise, then it has also to be adhered to. This explains the fact that resistance has almost collapsed in spite of the existence of widespread outrage. As a consequence, the government can be particularly brutal, and still actually rely on the support of a large majority of the population ${ }^{12}$.

And this shows that this is also social democratic policy. Instead of widespread terrorism as practised by the former military regime, the aim is now to achieve a compromise, a reconciliation. However, those who are not willing to participate in working towards the compromise deemed necessary, are subject to ruthless government pressure.

Concealed behind a rhetorical criticism of capital which indirectly shifts the blame for the crisis onto the Chaebol management, there is a far reaching strategy of rationalisation with its basis in a radical acceleration of the process of capital concentration. In keeping with the "strong state" policy of past decades the new president has stated: "Regardless of the size of companies, ones making profits will be treated as patriots by the new government. We cannot help the others and they will be left to go bankrupt" (Kim Dae-Jung in his programmatic speech made on 16.02.98., cf. Korea Times 17.02.98). The number of "core corporations" is to be reduced from the current 30 to tive or six (ibid.).

Government insiders are fully aware of how problematic and contradictory his strategy is. A close advisor to the new President, Prof. Choi Jang-Jib, Korea University, has urgently pointed out what is in the eyes of the government a real danger, that the government could be crushed between the Left and the Right, should their reform policies not make any convincing inroads. The new government ought therefore to ensure that their policies are founded on close relationships to all social groups (Korea Times, 17.02.98). 
Kim Dae-Jungs' programme of seemingly promising everything to everyone, is understandable against the background of these considerations. Some of the important point of the programme are:

- To attract foreign capital through legislation to facilitate mass redundancies, through massive support for foreign investments even going as far as to promote "hostile take-overs", the establishment of "4ree production zones" with additional tax advantages efc. as well as the continued liberalisation of the capital market.

- Privatisation of state-owned enterprises.

- Establishment of an unemployment fund and job creation schemes (as a concession to unions participating in the tripartite negotiations).

- An extension of union rights, also for the public service sector and even for teachers (concession from the tripartite negotiations).

- Reform of the elitist and ineffective education system.

- Introduction of Western-standard human rights.

- New policy with regard to North Korea: Freedom to receive North Korean radio and television transmissions, support for investment in North Korea, a summit meeting between North and South Korea.

However, a commission is first be set up to process proposals regarding reforms to human rights as well as women's rights.

\subsection{Preliminary conclusions}

The new President had already begun campaigning on a kind of socialdemocratic platform before the "crisis" actually hit.

Classic social-democratic strategy would entail the possibility for sustained participation of the workers in the sustained productivity increases as their reward for being party to an imperialist project. The preceding Korean model of accumulation had obviously not permitted this. The development after 1987 in particular, though, seemed temporarily to have brought such a strategy within the realms of possibility. The foreign direct-investment offensive in the wake of the overvalued Won would appear to have created some of the necessary conditions.

The policy of the democratic trade unions in particular, but also large segments of the democratic public, has sought orientation to the example of West Europe. Korea's participation in the imperialist scheme, though, as well as its reward remained dependent on the goodwill of organisations of world capital. 
The essential component of social-democratic strategy is the notion of overall appeasement of society within a "class compromise" as much as possible, which implies simultaneously a strategy of exclusion.

\section{Contours of a new mode of accumulation in South Korea}

\subsection{The domestic dimension}

Korean society is undergoing reconstruction in the wake of pressure from the world market. Kim Dae-Jung is probably just the right president in this situation. This is due to the great expectancy his people place in him with regard to the struggle for democracy. On the grounds of these expectations he will be able to call for painful sacrifice, since the majority may well react with anger, but finally with resignation.

It is to be expected that those whose wrath is still greater than their resignation will be the object of severe repression, not any longer as North Korean spies, but as anti-patriotic elements. Should what I described earlier as "identification with the aggressor" still apply, then this might result in the wrath being turned on the minority. They will experience even more difficulty in articulating themselves against repression, since it will not be possible to recreate the broad concensus achieved under the military dictatorship of the eighties against the then common enemy.

Due to the fact, that the material means for achieving the class compromise are normally not made available, the "appeasement" must necessarily rest more on ideology and repression. That means that the new accumulation mode will be along neoliberal lines.

However, it is already possible to foresee that the new Korean mode of accumulation, at least temporarily and in comparison with other countries organised along neo-liberal lines, will attain a high level of efficiency. This is because the longterm effect of introjective identification has obviously lost none of its influence and the readiness to self-sacrifice has once again been reactivated.

Propects for the effectiveness of such a development seem to be limited, though. Since the opportunities for extensive exploitation have disappeared and also the exploitation of environmental nature is reaching its utmost limits, a renewed increase of intensity presents the sole possibility.

This can only result in: Even more stress, even more substitution of material by immateriai compensation, i.e. further aggravation of addictive society.

As pointed out, these possibilities are restricted. Rising mass unemployment means that one of the typical forms of addiction, viz. addiction to work, no longer 
presents itself to a growing number of people. The onerous development of past years towards an increase in violence in society will continue its path.

This on the whole self-destructive process is likely in the long term to place severe restrictions on the process of capital realisation.

\subsection{Repercussions for other economies}

One part of world capital, viz. at first the Korean location, has been drastically devalued. On this new basis, implying in particular a reduction in the level of life for the workers in Korea, new opportunities are arising for the realisation of other parts of world capital, because they are now able to participate in the significantly more favourable conditions of exploitation ${ }^{13}$.

Due to the devaluation of the Won, Korea is now in intensified competition with other, previously weaker "emerging economies", because it offers higher quality products, or at least those which are perceived as such. These economies will be forced to "come into line", leading to subsequent devaluations and restrictions on their standard of living.

The competitively priced Korean products on the world market will place countries with precarious balance of payments in difficulty due to the stimulation for imports. They will attempt to react with import restrictions, thus provoking confrontation with the recently negotiated WTO rules ${ }^{14}$. They, too, will eventually be forced in the medium term to revert to a neo-liberal strategy.

By creating "factual constraints" the crisis is performing the function of bringing about a corrective adjustment of global structures.

\section{The search for an alternative}

\subsection{Does an alternative to the new mode of accumulation exist?}

The subject under investigation here is the future development in Korea, but 1 am not so much concerned with proposing solutions to abstract problems, e.g. how politics might enable an alternative, perhaps "more just" distribution of the burden of the capitalistic process of accumulation.

The question of alternative is therefore: Can development leave the path of addictive society based on introjective identification?

13 Cf. "The conclusion must be that Korea is today the most attractive investment opportunity in Asia”. (Dornbusch 1998).

14 This currently applies to Mexico and most other Central and South American countries. 


\subsection{Observations on the debate within the unions}

The scenario of future capitalistic development in Korea is obviously unacceptable to the vast majority of the people.

Apart from the first reactions of shock to the IMF dictate which tended to be confined to radical expressions of nationalistic fervour, calls for strikes, which just a year ago led to large protest demonstrations, went unheeded.

This is due to fear. It is the same fear which has accompanied the entire period of capitalistic development in Korea and which had only been suppressed superficially in the wake of the temporary, apparently generous participation in GDP. This fear currently manifests itself in radical words -by sections of the Left, for instancepartly in blind actionism, and partly by "moderates" in assuagement rituals, referring to "widespread unity of the people", but providing no evidence for it, calling for a "movement of workers with the people" and then warning against "self-isolation". Large sections of the union movement are still clinging to the hope that there will somehow be a social-democratic solution. Quite apart from the material impossibility of a welfare-state strategy described above, there would also appear to be a lack of awareness of the consequences of social-democratic politics. For far too long, Korean trade-unionists have virtually made pilgrimages to Germany, exploring the German unions' secret of success. Frequently, the differences in history and world politics between the two countries seem not to have been taken into account (cf. Heide 1996).

Traditional union politics, though, necessarily and always entail discriminative differentiation and ultimately exclusion. Representation of minority groups, of foreigners, of the unemployed, etc. has for ever been the "weak spot" of union politics. The ten years since the new democratic union movement came into existence have proven that this applies to an especially great extent in Korea.

A strategy, that in the ultimate instance results in exclusion and thus in a breakup of solidarity, helps to reinforce the system: Its basis is fear, which it reinforces. Fear of exclusion leads to an attitude of compliancy, which in turn reinforces the exclusion, and so forth.

Fear can never provide a basis for an alternative.

\subsection{Competition and solidarity}

If it is true thai fear constitutes the real basis of alienation, then it follows that the search for an alternative must be involved with possibilities for learning to cope with this fear and for developing conditions of living, working and of struggle which facilitate this process. The self-reinforcement of recovery must take the place of selfreinforcement of destruction. 
The first step would be recognition of the fact of fear, and thus breaking with a paralysing taboo. A second step would be the precise unmasking and designation of the mechanisms which have led to the perpetuation of fear through division: men from women, "active" from "lazy", healthy from handicapped, young from old, productive from unproductive, natives from foreigners, political activists from political prisoners and, a new phenomenon, employed from unemployed! The third step ought to be the acceptance of responsibility for collaborating with this system of dividing. It is not the system as such which brings about division, but rather the behaviour inherent to the system, which is adopted by all involved. Even those who see themselves as victims take part in this.

It is always easy to make accusations: "The system disadvantages women in favour of men". The vital concretization consists of the question: "What is the relation between men and women in the unions, in political groups, etc.?" It may be taken for granted by liberally-minded persons that one should not discriminate against migrant workers; but how do the unions react to concrete cases of discrimination? And are migrant workers admitted to the unions, or excluded because they "are only here for a short time in any case", or possibly, "because they are illegal"? And the unemployed? Often the co-operation fails, even with workers dismissed for political reasons. How to reach a solution to this problem when several million will be out of work? And how do the unions tackle the issue of political prisoners?

Acceptance of responsibility means to recognise these problems and to search for solutions. Acceptance of responsibility is thus not to be confused with "taking the blame". It is prerequisite for conscious social action. The development of solidarity is the conscious withdrawal from competition, a renouncement of division.

The tangible result of solidarity in this sense is in a real and substantial reduction of fear, the fear of being excluded. Thus solidarity of the still working with the jobless is never an altruistic self-sacrifice ${ }^{15}$, it is rather the return to selfresponsability. In this sense we can say, that the social struggle receives a new "moral" boost. It has to do with much more than the mere "just" participation in the fruits of exploitation. And on this basis, too, the term "international solidarity" can at last become more than a slogan for a tactically deployed and limited suspension of real competition, it may become the first step of withdrawal from the wake of the neoliberal offensive.

The alternative can never be the final goal; rather, it is the path to get there.

15 By the way, solidarity can never be based on pity. It is the principle of pity on which the new president falls back, when he exhorts leaders of local religious communities to "rescue the 1.5 million unemployed". Kim said this in a "national prayer breaklast" at the Hilton Hotel on March 25, 1998. Regarding the concept of pity as key element of capitalist social policy, see Dörner 1988. 


\section{REFERENCES}

Chang, Ha-Joon (1993): The Political Economy of Industrial Policy in Korea. In: Cambridge Joumal of Economics. Vol. 17. pp. 131 - 157.

Cumings, Bruce (1997): Korea's Place in the Sun. New York.

Dornbusch- Rudi (1998): Why investors should favour Korea. In: Digital Choson Ilbo - English Edition, 05.03.98.

Dörner, Klaus (1988): Tödliches Mitleid. Zur Frage der Unerträglichkeit des Lebens oder: die Soziale Frage: Entstehung, Medizinienung, NS-Endlösung, heute, morgen. Gütersloh.

Ferenczi, Sándor (1933): Sprachverwirrung zwischen dem Erwachsenen und dem Kind. Die Sprache der Zärtlichkeit und der Leidenschaft. In: Schriften zur Psychoanalyse. Vol II.

Gruen, Amo (1997): Der Verlust des Mitgefühls. Über die Politik der Gleichgültigkeit. München.

Gruen, Amo (1986): Der Verrat am Selbst. Die Angst vor Autonomie bei Mann und Frau. München.

Hartmann, Detlef (1988): Die Alternative. Leben als Sabotage. 2. Aufl. München.

Heide, Holger (1998): The Creation of Individual and Collective Strategies of Survival as a Pre-condition for Capitalist Development - The Case of South Korea. In: Proceedings of the Fifth International Conference on Korean Studies. University of Osaka. Forthcoming.

Heide, Holger (1997a): A New Pradigm of Work. Lecture at the International Symposium on The Future of Work and Labor. 30./31. Mai 1997. Seoul. Forthcoming.

Heide, Holger (1997b): Soziale Implikationen der erfolgreichen Strategie der Weltmarktintegration SüdKorea. Arbeitspapiere zur soziallökonomischen Ost-Asien-Forschung. Nr. 1. Universität Bremen.

Heide, Molger (1996): Hanguk nodong-undongeseo Togil nodong-undongeul paraboneun sigake Taehan pip'anjeok kyeonhae (Some critical remarks to the attitude of Korean unions to German labour movement). In: Hyeonjangeseo miraereul (Monthly Review of the Korean Institute for Labor Studies and Policy, Seoul). No. 11. June, 1966.

Heide, Holger (1996): China - Korea. Koreanische Direktinvestionen in China und chinesische Arbeiter Innen in Korea. In: Bass, Hans. H., Wohlmuth, Karl (Hg.): China in der Weltwirtschaft. Hamburg.

Henderson, G.A. (1968): Korea. The Politics of the Vortex. Cambridge.

Hirsch, Joachim (1995): Der Wettbewerbsstaat. Berlin. 
Hirsch, Mathias (1986): Zwei Arten der Identifikation mit dem Aggressor - nach Ferenczi und Anna Freud. In: Praxis Kinderpsychologie und Kinderpsychiatrie. Vol. 45. pp. 198 - 205. Köln.

Hwang, Ki-Don (1996): Ökonomische Entwicklung und Lebenswirklichkeit von Arbeiterfamilien in Südkorea. Hamburg.

Kang, Su-Dol (1996): Globalization of the Labor Market in South Korea. Manuscript of a Lecture hold at the International Conference on the Dynamics of Labor Migration in Asia. Tokyo.

Kang, Su-Dol (1995): Fordismus und Hyundäismus. Frankfurt am Main.

Kim, Eun-Young (1997): Wandel der Intimität und Männer in der koreanischen Familie. Manuskript eines Vortrags auf der koreanisch-deutschen Soziologenkonferenz "Globalisierung und kulturelle Identität", 26 - 28. Mai 1997 an der Akademie für Korea-Studien in Seoul.

Krugman, Paul (1998): What happened to Asia. http//web.mit.edu/krugman/www/ DISINTER.html

Krugman, Paul (1997): What ever happened to the Asian Miracle? In: Fortune, Aug.

Krugman, Paul (1994): The Myth of Asia's Miracle. Foreign Affairs, Voll. 73 Nr. 6.

Lee, Chung H. (1995): The Economic Transformation of South Korea. Lessons for the Transition Economies. OECD. Paris.

Lee, Eun-Jeung (1997): Konfuzianismus und Kapitalismus. Markt und Herrschaft in Ostasien. Münster.

Leftwich, Adrian (1995): Bringing Politics Back In: Towards a Model of the Development State. In: The Journal of Developmental Studies. Vol. 31, No. 3, Feb. 1995. London.

Lowen, Alexander (1989): Fear for Life. New York.

Marx, Kart (1993): Grundrisse: Foundations of the Critique of Political Economy (Rough Draft). Harmondsworth. (The quotations in this paper are from the German original published for the first time in Moscow 1939: Grundrisse der Kritik der Politischen Ökonomie. Rohentwurt).

Palley, Howard A. (1992): Social Policy and the Elderly in South Korea. In: Asian Survey. Vol. 32, No. 9, pp. 787 - 801.

Sachs, Jeffrey D. (1997): Asia's Miracle is Alive and Well. In: Time, Sep. 29.

Schaef, Anne Wilson and Fassel, Diane (1988): The Addictive Organization. San Francisco.

Shim, Jae-Hoon (1997): Rose-Tinted Glasses. A troubled nation revives its former military leader. In: Far Eastern Economic Review. July 17.

Thompson, Edward P. (1967): Time, Work-Discipline, and Industrial Capitalism. In: Past and Present. 38. pp. 56 - 97.

Thompson, Edward P. (1968): The Making of the English Working Class. Oxford. 